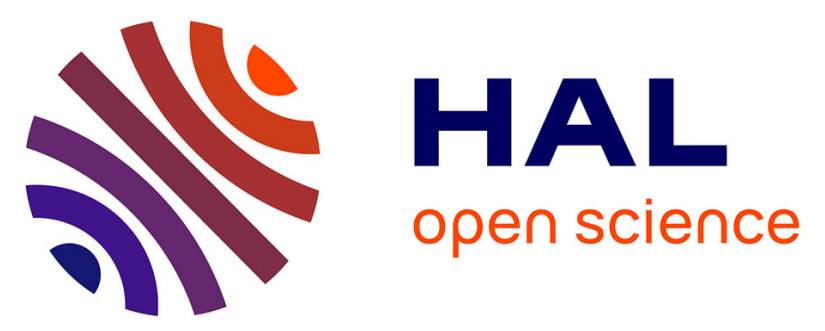

\title{
Food chains; the cradle for scientific ideas and the target for technological innovations
}

Joel Abecassis, Bernard Cuq, Jean-Louis Escudier, Gilles Garric, Alain Kondjoyan, Veronique Planchot, Jean-Michel Salmon, Hugo de Vries

\section{- To cite this version:}

Joel Abecassis, Bernard Cuq, Jean-Louis Escudier, Gilles Garric, Alain Kondjoyan, et al.. Food chains; the cradle for scientific ideas and the target for technological innovations. Innovative Food Science \& Emerging Technologies / Innovative Food Science and Emerging Technologies , 2018, 46, pp.7-17. 10.1016/j.ifset.2017.09.011 . hal-01604501

\section{HAL Id: hal-01604501 \\ https://hal.science/hal-01604501}

Submitted on 26 May 2020

HAL is a multi-disciplinary open access archive for the deposit and dissemination of scientific research documents, whether they are published or not. The documents may come from teaching and research institutions in France or abroad, or from public or private research centers.
L'archive ouverte pluridisciplinaire HAL, est destinée au dépôt et à la diffusion de documents scientifiques de niveau recherche, publiés ou non, émanant des établissements d'enseignement et de recherche français ou étrangers, des laboratoires publics ou privés.

\section{(ㄷ)(1)(2)}

Distributed under a Creative Commons Attribution - ShareAlikel 4.0 International 


\section{Accepted Manuscript}

Food chains; the cradle for scientific ideas and the target for technological innovations

Joel Abecassis, Bernard Cuq, Jean-Louis Escudier, Gilles Garric, Alain Kondjoyan, Véronique Planchot, Jean-Michel Salmon, Hugo de Vries

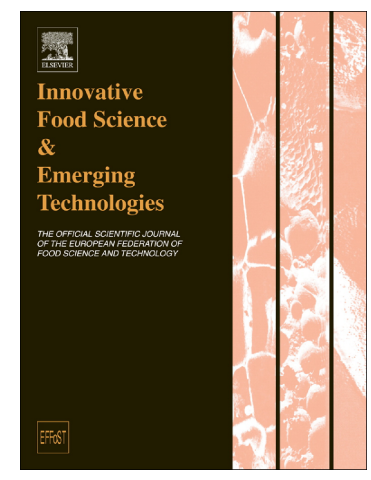

PII:

S1466-8564(17)30219-9

DOI: doi: 10.1016/j.ifset.2017.09.011

Reference:

INNFOO 1849

To appear in: Innovative Food Science and Emerging Technologies

Received date: 21 February 2017

Revised date: 8 August 2017

Accepted date:

13 September 2017

Please cite this article as: Joel Abecassis, Bernard Cuq, Jean-Louis Escudier, Gilles Garric, Alain Kondjoyan, Véronique Planchot, Jean-Michel Salmon, Hugo de Vries, Food chains; the cradle for scientific ideas and the target for technological innovations, Innovative Food Science and Emerging Technologies (2017), doi: 10.1016/j.ifset.2017.09.011

This is a PDF file of an unedited manuscript that has been accepted for publication. As a service to our customers we are providing this early version of the manuscript. The manuscript will undergo copyediting, typesetting, and review of the resulting proof before it is published in its final form. Please note that during the production process errors may be discovered which could affect the content, and all legal disclaimers that apply to the journal pertain. 
Food Chains; the cradle for scientific ideas and the target for technological innovations

Joel Abecassis ${ }^{1}$, Bernard Cuq ${ }^{2}$, Jean-Louis Escudier ${ }^{3}$, Gilles Garric ${ }^{4}$, Alain Kondjoyan ${ }^{5}$, Véronique Planchot ${ }^{1}$, Jean-Michel Salmon ${ }^{3}$, Hugo de Vries ${ }^{1 *}$

\author{
${ }^{1}$ UMR IATE, CIRAD, INRA, Montpellier SupAgro, U. Montpellier, 2 Place Viala, 34060 Montpellier, France \\ ${ }^{2}$ UMR IATE, Montpellier SupAgro, 2 Place Viala, 34060 Montpellier, France \\ ${ }^{3}$ Inra UE 0999, Unité Expérimentale de Pech-Rouge, 11430 Gruissan, France \\ ${ }^{4}$ UMR STLO, Agrocampus Ouest, INRA, 35000 Rennes, France \\ ${ }^{5}$ UR QuaPa, INRA Site de Theix, 63122 Saint-Genès-Champanelle, France
}

Corresponding author: hugo.de-vries@inra.fr

\begin{abstract}
:
Research in the area of emerging food science and technology is still often carried out in agri-food chain perspectives, as presented here in four different ways for dairy, meat, wine and cereal cases. The key focus is on the concept of food quality throughout the chain, and the meaning of added value and food functionalities for consumers. Technology innovation approaches essentially address ways to optimize and maintain food quality according to consumer preferences, needs and acceptances. However, they also strive to reduce the environmental impact of the transformation of agroresources into food products, via targeted and intensified processing schemes requiring minimal energy and water usage, as well as value-streaming co-products of used agroresources-which holds for all the chains presented. Another key area that emerges from the cases is protein science, which concerns agroresources rich in specific protein and, protein heterogeneity, structural changes, profiles, functionalities and nutritional value. This analysis further highlights the importance of linking food science and technology to agronomy, genetics, and socioeconomic sciences. Finally, knowledge management is becoming increasingly integral to food chain research in order to increase transparency and capitalize data in a consistent manner.
\end{abstract}

Key words: food chains, processing innovations, food quality, sustainable food chains, market trends, consumer demands.

\title{
Introduction:
}

The food sector, especially the food manufacturing industry, is still very much supply chain-oriented and specialized into product categories (meat, dairy, fruit, vegetables, etc.) -FoodDrinkEurope represents 27 sectors (2016) and ANIA 23 in France (2016). This sector structure holds for the primary sector as well as retail-where product categorization is very well visualized - and even in world trade offices and stock exchanges. Numerous research organizations are equally product- and sector-oriented (beer, wine, dairy, meat, etc.), equipped with specific pilot-scale processing lines for research and innovation to solve bottlenecks while mimicking real-life manufacturing conditions (HighTechEurope, 2016). Consequently, a number of research and innovation projects have been carried out in a product chain context. This work has favored big companies via economies of scale for single product output lines, but it has also allowed smaller companies to compete with added value, innovative and/or distinctive products leveraging place-of-origin effects, traditional roots, etc. (Trafoon, 2016; TradelT, 2016). The value of R\&D infrastructures should not be underestimated, as they allow companies to access external knowledge and run tests with the latest equipment without the need to continuously renew their own equipment, and without having to interrupt their ongoing manufacturing process for product development and testing. 
There are several benefits to organization in a food supply chain, defined as a system of organizations, people, activities, information, and resources involved in moving a product or service from supplier to consumer (Supply Chains, 2016). First, it allows efficiency in food delivery, as it aligns production of raw materials to processing conditions and end- product characteristics according to consumer expectations. Second, it facilitates rapid responses to consumer preferences, demands and trends (demand chains) (Grunert, 2005). A key example of the past decade is the trend towards fresh convenience. In numerous product categories this has been translated into new products and new packaging concepts. Third, its linear operation provides transparencies in transactions and logistics. Tracing and tracking, new coding systems, labelling and claims have been introduced and are relatively well incorporated in the overall food sector. Fourth, its strong connections make it possible to vertically innovate from farm to fork and from fork back to farm, and to verify trade-offs (Gwanpua et al., 2015). Innovations in genomics have been translated into new product characteristics, better adaptability to the environment, and more. Fifth, it allows to set common goals, such as reducing pesticide use and its consequences in the full chain, banning fertilizer inputs and its consequences for product quality. This paper illustrates numerous examples of research rooted in chain perspectives and innovations reached in food science and technology. Future perspectives demonstrate the need for research to continue in chain perspectives (Esnouf et al, 2011).

There are also several drawbacks to organization in linear supply chains. First, new generic insights cannot always be obtained in individual chains, which is especially important when dealing with highly complex issues like food-health linkages. Second, it can hinder the exchange of best practices between chains, which can prove important in waste-to-value efforts (Matharu et al., 2016). Third, several key societal challenges like food security, climate change, soil erosion, urbanization and maintenance of biodiversity and ecosystems require cross-chain thinking, and thus complex food system approaches in which all food and food-impacting activities interact. Fourth, new bio-economy and circular economy concepts require full usage of diverse agroresources for multiple applications including non-food products (de Vries, 2017), and thus-again-a complex system approach. The growing world population and the footprint of the agro-food sector mean that all future food demand and supply chains have to become increasingly efficient in order to sufficiently produce food while substantially reducing waste and valorising co-products ${ }^{1}$.

In this setting, the INRA's CEPIA division together with partner research centers across France are focusing on food science and technology in individual chains, as presented here, as well as more generic scientific issues like biopolymer science, consumer science, modeling and process engineering, as presented elsewhere in this Special Issue. Note that that all cases are presented in a somewhat different way in order to reveal the richness and diversity of the chains, but all with the same societal and scientific challenges and perspectives for innovative food science and emerging technologies. The wine case is described as a business case revealing strong French roots, environmental pressures, market opportunities and strengths and weaknesses. The meat case is considered from the sustainability and food \& health perspective to counteract the more publicized negative images of the meat chain. The dairy case is very much oriented towards international competitive positioning for major dairy products, but it also illustrates the huge diversity of regional (cheese) products. The cereal case is highly single cereal-oriented, focusing on an innovative organizational approach to increase the competitiveness of the French durum wheat chain.

\footnotetext{
${ }^{1}$ There is a plethora of scientific literature on food supply chains (and supply chains in general), including all the various chain system descriptions, from supply chains and demand chains to value chains which encompass both supply and demand chains. A full review of these publications, with their strengths and weaknesses, is outside the scope of this chapter.
} 


\section{Case 1: The vine $\&$ wine chain}

\subsection{Socio-economic, historic, cultural and heritage importance of the French wine-producing sector.}

Although winemaking knowledge spans a period of over 2000 years, wine research and experimentation have never been as active as today in the 'New World' wine countries (US Davis in the USA, Stellenbosch in South Africa, the AWRI in Australia, ITA in Argentina) as well as in the more traditional ones (Italy, France, Spain). To illustrate the fact, a survey on the French wine sector found 1187 publications over the 2008-2012 period (Fournier, 2014). The globalization of vineyard plantations is directly related to economic development, risks and opportunities tied to climate change, and shifting consumer habits, prompting all countries to evolve-even the traditional homelands. The wine sector stands out from other agro-food sectors. In Europe, especially around the Mediterranean Basin, wine is a cultural product with long-standing historical value. Vine growing wields a huge influence on local cultures and holds an undeniable heritage role, as the human being remains a dominant factor in the articulation of knowledge. New World wine countries have opened up to the production and consumption of wine, and even to wine tourism. Vine is a long-lived plant that only starts to produce in its fourth year, yet standing surface areas of vines continues to grow.

Despite fierce competition, France and Italy remain the world's leading producer countries. France counts more than 80,000 wine-farm operations, corresponding to about 250,000 direct jobs, and the majority of these farms are smaller than $50 \mathrm{ha}$, although size varies hugely due to local wineproducing conditions. Production tends to focus around the family circle to preserve employment in rural areas. There are only a few international brands outside the Cognac and Champagne production areas. As the third most practiced crop in France, vineyards account for $3.7 \%$ of the French utilized agricultural area (UAA) and about $20 \%$ of all pesticides, volume-wise. One of the stand-out features of the sector is its huge diversity, both at production level and organizational level. A recent forward-looking survey of the French vine and wine sector performed by the INRA (Sébillotte and al., 2003) has raised the stakes in terms of partnerships and identified about a hundred actors, job specificities, cooperative models and trade unions. The decision centers for vine and wine research are partly harmonized in a French executive frame (INAO, DGCCRF) but mostly in European and global structures through the OIV (Office International de la Vigne et du Vin) that counts 46 member states representing $85 \%$ of worldwide wine production. OIV experts issue recommendations that are mostly adopted at EU level, lending these regulations statutory value.

\section{Specificities of the wine sector in food-processing industry-related research.}

The 'soil, vineyard, grape and wine' continuum should be covered in future research taking into account environmental and qualitative approaches. For analysis, the following issues emerge:

a. The plant material: France continues to cultivate the same one species (Vitis vinifera L.). Its capacity in terms of vegetative cloning allows almost identical reproduction of plants of the same variety. Approximately 200 different vine varieties are registered in the French catalogue, but just 15 represent $85 \%$ of all grapes planted in France. Every year in France, 200 million plants are sold to ensure the renewal of 800,000 ha of vineyards. The list of vine varieties authorized for AOP and IGP wine productions is strongly regulated and defined by legislative decrees. Global climate change and extensive use of pesticides are driving a gradual change in the vine varieties currently used (Ojeda et al., 2016), which will have serious impact for the future of the wine sector.

b. Production systems: The wine sector features a broad diversity of production systems, which are mainly conventional, partly intensive (about $10 \%$ ), rational and integrated (8\%) with alternative solutions to weed killers and insecticides, and small but fast-expanding organic and biodynamic vine 
production (6\%). Organic vineyard farming is governed by EU regulation 2092/91. EU governmentapproved certification bodies assure compliance with these specifications, which gives the right to use the word "organic" and the "AB" logo (Trioli et al, 2009). The EU regulation allowing labelling as "organic wine" was extended to winemaking from August $1^{\text {st }} 2012$ (Salmon, 2010). Since February $8^{\text {th }}$ 2012, rules on organic winemaking (CIR 203/2012) complete the EU organic regulation (EC) 834/2007 allowing certification of the transformation process and thus also the wine, not just the grapes.

c. Wine, as final product: The huge array of different wines (more than 500,000 commercial references in France) is divided into still wines, sparkling wines and liquor sweet wines. Like other fermented drinks (beer, cider), wines are not yet compelling to state inputs and additives for processing on their labels. According to French legislation, additives are distinguished from technological auxiliary agents which are not present in the final product. Once wine-labelling is made compulsory, consumer research will become even more critical. One of the challenges of tomorrow's oenology research is to develop high-quality wine with less or zero inputs. As bottled wine has a much longer shelf-life than any other processed food, the key research question will be how to maintain and develop wine quality during storage, with particular focus on how to manage oxidation (and reduction) phenomena using minimal sulphite, which is a known allergen (Salmon, 2012). Note that the aging wine, contrary to many other stored products, enhances its final quality.

d. Quality markers: The wine sector has defined various quality markers that structure the market and define the conditions for the evaluation of the final product. Wines are classified according to three statutory categories established within the framework of the EU-market system:

- Wines without geographical indication (VSIG or " Wine of France " without GI),

- Wines with protected geographical indications (PGI),

- Wines with protected designations of origin (PDO or AOC in France), ruled by specifications at the level of each of the 318 PDO and 73 PGI.

In 2016, nearly $50 \%$ of wines in terms of volume corresponded to PDO wines, and $28 \%$ to PGI wines. Wines are sold and marketing through diverse channels, including direct selling in the cellar, selling through cooperatives, or sales by traders, all utilizing different forms of packaging from the classic bottles to bulk wines, bag-in-box, etc. New wine packaging solutions (BiB, PET bottles) are a focus of specific research (Vidal et al, 2011; Toussaint et al, 2014), since wine for export is well-conditioned until the moment of consumption. Research on managing quality parameters is directly related to vine growing and winemaking. The translation of research results and/or consumer preferences and market opportunities into innovations takes years (typically 10-15), and even more when local adoption (as in Spain and Italy) and legal acceptance (OIV, Europe, PGI or PDO) are added.

e. Environmental and pedoclimatic conditions and symbolic varieties of wine-producing areas: Wine production and final quality and composition are very strongly impacted by local environmental and pedoclimatic conditions. French vine-planting areas cover diverse landscapes (plains/hillsides) and pedoclimatic conditions, and there are further challenges to counteract diseases depending on Mediterranean, Atlantic or northern pedoclimatic conditions. Finally, the availability of fresh water resources is becoming a huge concern due to changing intensities of rainfall and periods of drought. Although the picture is different between Global North and Global South, overall, climate change is leading to hydric stress (Escudier et al, 2014; Dequin et al., 2016). These issues are addressed by the large wine-producing French regions that finance inter-professional organization centers with their own experimental facilities.

f. Diversity in socio-economic models: Winemaking farming systems adopt different winemaking strategies depending on their production, marketing, (direct or indirect) sales, organizational setup (e.g. a cooperative structure), trading channels, etc. The vineyard is a long-lasting crop investment, so grape varieties and modes of vine dressing have to be chosen very carefully, and thus require a 
long term strategy and sustainable practices. In the mid-term, producers should be given guidance to help overcome periodic constraints and the potential consequences thereof.

\section{Strengths and weaknesses of French research in the wine sector.}

The issues outlined above and the strengths and weaknesses of the French wine sector require the development of a robust, well-structured and nationally-coordinated research strategy with input from the INRA, the IFV (French Wine \& Vine Institute) and a network of regional Chambers of Agriculture for research and experimentation. The oenology laboratories, input suppliers and equipment manufacturers should be the operational levers at local level. The following thoughts should be included in the debate:

- The distillation and selling of alcohol and the value-chain of some co-products by distillers (such as phenolic compounds, coloured pigments, etc.) allow winemakers to finance cellar wastes depollution, free of charge. This specific circular economy model in France is suffering due to the abolition of financial support for distillation, but it should be re-discussed now that there are novel technologies and new waste-to-value pathways for co-products, such as those researched in the ongoing EU Project NOAW (NOAW, 2017): the utilization of tannins for biomaterials is a good example.

- In a sound bio-economy context, it is necessary to improve the conditions for grape harvesting and to develop precision oenology to reduce input and additive use and healthhygiene risks in winemaking (Escudier et al., 2012).

\section{Towards an innovative vine and wine science and technology agenda.}

Relatively strict qualitative specifications on the wine product and its composition should be defined at every stage of the transformation process, from the moment of harvesting up to the consumption of a glass of wine. This involves setting up a no-defect oenology methodology and defining quantifiable identifiers for wine quality, which is a prerequisite in order to converge the development of new innovations in the sector with assurances of final product acceptance by the consumer. At the first pre-fermentative technical steps, it is important to understand and improve both the extraction phenomena and the clarification of musts, by developing mechanical instead of input-based interventions. Second, the management of oxygen and the implementation of a continuous process at least for the large production units-are important challenges. Alcoholic fermentation will be better mastered by an in-line follow-up approach that allows feedback and feedforward interventions. Next, control of the physical-chemical evolution of wines, and specifically their redox levels, is a field of ongoing research related to final wine quality. Its development will depend, in particular, on the definition of new membrane materials for filtration and electrodialysis, and new highly-sensitive measurement devices. Finally, it is crucial to involve geographical indication agencies, trade associations and inter-professional organizations in the definition, management and control of wine quality evaluation.

The winemaker generates a large amount of observational data in every vintage, and the increasing use of sensors in the vineyard and in the cellars also generates new data. All this information remains widely under-exploited, creating a real challenge for knowledge capitalization in various forms (digital, expertise, etc.).

\section{Case 2: The Meat chain}

\subsection{The French meat chain}

Meat and milk chains begin by animal production. Around $75 \%$ of French UAA is used for livestock production, $2 / 3$ of which is grasslands. Livestock production is often criticized as resource-intensive, 
competing with the direct production of other foods for humans and contributing to climate change. Livestock production requires a lot of water (the average water requirement for beef cattle is estimated at 15,000 L of water per kg of beef weight) and cereals, especially in intensive farming systems. Ruminants also produce GHGs, including enteric methane which has a big equivalent carbon footprint. However, these elements must be put into perspective by the fact that animals can draw value from surfaces and foods that are unsuitable for humans (grass, co-products from agriculture and industry, etc.). In addition, grazing systems deliver a large number of often-forgotten ecosystem services: carbon storage in pasture soils, maintenance of soil fertility and biological activity, maintenance of animal and plant biodiversity, reduction of pesticide use, greater resistance of lands to fires and storms, etc.

\subsection{The nutritional value of meat consumption}

Meat products are essential for human nutrition and food security worldwide. They currently provide about $26 \%$ of total protein consumption and $13 \%$ of all calories (FAO, 2009). For protein alone, 100 grams of cooked meat covers $35-60 \%$ of the recommended nutrient intake (RNI) of an adult man (Martin, 2001; AFSSA, 2007). Nutritionally speaking, meat has the advantage of containing all the essential amino acids and in balanced amounts relative to human needs-whatever the species, 100 $\mathrm{g}$ of cooked meat covers $70-200 \%$ of the RNI of amino acids depending on amino acid profile. Furthermore, the digestibility of meat proteins is high, between 90 and $95 \%$, even after cooking (Bax et al., 2013). Meat is also a valuable source of iron, zinc, selenium and B-group vitamins, as $100 \mathrm{~g}$ of cooked meat covers $20-80 \%$ of RNI in zinc, $18-25 \%$ in selenium, $50-100 \%$ in B12, 30-50\% in B3, and is a valuable supplement in terms of B6 content (AFSSA 2007; Duchene \& Gandemer, 2016). The diet contribution of "red" meat is also important, especially when factoring in the bioavailability of heme iron. The RNI was defined for dietary iron in general, with an average intestinal absorption coefficient estimated at $10 \%$. On this basis, for example, $100 \mathrm{~g}$ of braised cheek would cover $23 \%$ of the RNI of iron for a man and $13 \%$ for a woman (Duchene \& Gandemer, 2016). However, after factoring in the better absorption of heme iron, the contribution of cheek meat becomes $45 \%$ of RNI of iron for a man and $26 \%$ for a woman. This is especially important for adolescents and premenopausal women who have high iron requirements: in France, $25 \%$ of women of childbearing age have low iron stores, and $5.7 \%$ are anemic (USEN, 2007).

\subsection{The evolution of meat consumption}

All food consumption projections point to an increase in meat consumed worldwide. The rate and level of increase remains debatable as they are based on dietary changes in developing countries which are difficult to predict with any real accuracy. One of the countries set to drive this increase is China, where meat consumption has already surpassed $50 \mathrm{~kg}$ per capita per year and will likely reach $80 \mathrm{~kg}$ per capita per year in 2030 (Pelletier, 2015). World population is predicted to reach 9 billion by 2050, so if consumption per capita remains at its current level, world consumption will increase by $30 \%$ - and even double if we consider the evolution in the quantity of meat eaten by the Chinese population. The FAO predicts an intermediate level in a 50-70\% range of increase. The index of animal consumption, which is the amount of food needed by the animal to produce $1 \mathrm{~kg}$ of meat, is 1.8 for poultry meat, and 3.0 for pork. The index for beef is higher than for pork, but depends on the proportion of grain and grass in the feed.

\subsection{Towards a new dietary balance in animal and plant proteins}

The future deficit in meat requires political measures and innovations in the field of animal production which are not detailed here. A dietary deficiency in animal proteins in the human diet can theoretically be compensated by a greater use of plant proteins, and vice versa. Appropriate plant protein resources should be carefully selected to achieve a balance in amino acids in the diet, as legume proteins for example are low in methionine and cysteine, while cereal proteins are poor in 
lysine. Moreover, plant proteins are often less digestible than meat proteins, can trigger allergies, and may cause product off-flavors. Consequently, further research is needed to process plants and integrate plant proteins in the diet. An innovative solution would be to combine plant and animal proteins in new food products different from those based on traditional uses of soya.

\subsection{Animal waste reduction and valorization of co-products}

Increasing animal-protein food security requires limiting losses and wastage of animal products all along the chain. This is true for all food products, but especially for meat due to its environmental footprint once we account for all the inputs and resources utilized up to the final end-product, for which Life Cycle Assessment (LCA) studies have managed to gather a fair amount of quantitative data in recent years. This waste challenge is particularly acute for beef because animal production in "western feeding-lots" requires high energy and water supplies, while grazing leads to the formation of GHGs. Scholtz, Eriksson and Strid (2015) calculated that 3.5\% of mass loss-as recorded for meat products in six Swedish supermarkets-accounts for $29 \%$ of total footprint wastage of these supermarkets. Some of the solutions to reduce meat waste are common to other food products (improving packaging, rationalizing portion size, etc.), and are based on informing and educating consumers and professionals and better understanding their behavior. From a food science and technology point of view, decreasing meat waste requires (1) a better preservation of product quality and (2) transforming meat-industry co-products into high-added-value products. The first point is being researched under the GloFoods metaprogram (GloFoods, 2016), a large multi-disciplinary INRA and CIRAD program dealing with scientific challenges for global food security. The second issue is especially important for the meat industry because less than half of animal weight is meat, and the other half consists of fat, blood, skin, bone, ligaments, etc., which are co-products that can be used in different ways depending on animal species and consumer dietary cultures. For example, in France, a lot of pig co-products like fat, leg bones and blood are used in traditional foods such as "saucisson"," pieds de porc", "boudin" (blood sausage), and so on, while in China and much of Asia pig ears are a traditional dish and proteins and minerals extracted from the bones are used as ingredients for traditional soups and dishes. Applications are even found in non-fully-registered medicines such as chondroitin sulfate. Another example is poultry legs consumed by Chinese and Vietnamese citizens, but rarely in European culinary culture.

\subsection{Towards an innovative meat food science and technology agenda}

As discussed above, the value-streaming of by-products warrants fresh impetus and continued effort as there are opportunities for ligaments as source of elastin, poultry feathers and cattle hair as a source of keratin, etc. The quality of the gelatin from bones or blood proteins needs to be substantially improved for further use in food and pharmacy industries (Saguer et al., 2008). Peptides from protein hydrolysates should be further researched for their bioactive properties in high-addedvalue products for biomedicine, pharmaceutics, and cosmetics (Gu \& Wu, 2016). Second, manual processing of carcasses and meat should be revisited for environmental and economic reasons. The water and energy inputs are substantial and could be reduced in completely new integrated process designs. Highly intelligent sensor-driven manufacturing, including the use of robotics, may also help reduce meat losses during processing. Third, meat consumption should be re-discussed to balance health and pleasure with environmental concerns at global scale taking into account the cultural diversity in meat consumption. Fourth, meat safety problems related to bacteria (Salmonella, Listeria...) or prions (bovine spongiform encephalopathy) warrants continued research effort, and today research is extended to the effect of meat on cardiovascular diseases and cancers. Many research projects have thus been focused on the effect of reducing fat and salt in cold and cured meat while maintaining their technological and sensorial properties (Bombrun et al., 2014, 2015, Harkouss et al., 2015), which remains a challenging scientific endeavour. Fifth, a new focus should be on the relationship between specific cancers and initial chemical contamination of meat, due to either animal feeds or pollution of the animal environment (Planche et al., 2015). 
Numerous questions are also posed regarding the formation of carcinogenic compounds during processing (Kondjoyan et al., 2010ab), the prevention of oxidation and nitrosation, connected with the presence of iron (Promeyrat et al., 2013) and the existence of nitrates/nitrites in the final meat product. A lot of European consumers remain fond of either beef steaks or roasts, but there is often a disconnect between the major sensorial traits for beef meat quality like tenderness, flavor and juiciness and what the industry can guarantee through meat grading and pricing, which results in a direct impact on meat-industry competitiveness (Hocquette et al., 2014). A new view on 'quality' should be based on a sound food science approach.

\section{Case 3: The dairy chain}

\subsection{The French dairy sector}

The French dairy sector is one the driving forces of the French economy. It represents an annual turnover of $€ 30$ billion, is France's second largest agri-food sector, counting 60,000 employees in the overall chain, and contributes to approximately $40 \%$ of agro-food trade ( $€ 3.7$ billion). In the past 10 years the dairy sector has undergone deep restructuring. Between 2005 and 2015, the number of dairy businesses fell by over 30\%, from 1120 in 2005 down to 760 in 2015. However, 5 of the top 25 global dairy companies are based in France. The organizational structure of French dairy businesses shows a remarkable 50/50 split, with half of them cooperatives and the other half private companies. They are collectively represented by the FNCL (Fédération Nationale des Coopératives Laitières) and the FNIL (Fédération Nationale des Industries Laitières), respectively. Together they form the CNIEL (Centre National Interprofessionnel de l'Economie Laitière) which is the decision making authority in the dairy domain in France. At national level, the CNIEL defines the collective actions and the scientific agenda (research programs, bibliography scanning, etc.) needed to reinforce the competitiveness of the chain actors (Economie laitiere en chiffres, CNIEL, Edition 2016). Figure1, presents the richness and diversity of the French dairy sector, with cheese products appreciated and recognizable at both global and local scales.

Figure 1. A map of the regions in France with all their typical cheese products

\subsection{Joint research and development programs}

TheFrench dairy sector is extremely strong and executes many public-private research programs, in particular with the INRA (joint research centres STLO in Rennes, Urtal in Poligny, and LRF in Aurillac), technical centers like Actalia and universities/schools like AgroCampusOuest and the Ecole Nationale d'Industrie Laitière. The strongest R\&D centers are based in the western part of France (Brittany Region). These centers perform both pre-competitive and competitive research as well as development and innovation programs. The INRA coordinates programs through the ANR (French National Research Agency) such as the Valobab project focusing on the nutritional value of phospholipids from buttermilk (Bourlieu \& Michalski, 2015, Gassi et al, 2016), and pools its platforms to optimally respond to dairy market challenges and problems. Another key example is the long-term integrated R\&D program called 'functionalized proteins for the dairy industry' (PROFIL) whose ambition is to create new "clean label" dairy products by improving the antifungal, texturing, vectorizing and emulsifying properties of milk proteins (see below). This 6-year program is supported by the Brittany and Pays de Loire regions, the INRA, and several universities and dairy processors.

\subsection{Examples of innovative food science and emerging technologies topics in the dairy chain}

The dairy products of tomorrow will be more and more complex and sophisticated. They will carry functionalities depending on target groups, like Lactel's "Sporteus" for sportsmen (certified via INSEP) and "Jour après Jour" (day after day) for the elderly. 
The complexity stems first from the modes of conception. Raw materials, either pure or mixed, are fractionated into basic building blocks and then restructured via concentration, separation, and purification of proteins, lipids, carbohydrates and minerals. The aim is to get an ideal biochemical profile corresponding to consumer demands. One example is 'breakfast on the go' combining dairy and cereal-based resources into smoothies, milkshakes, yoghurt drinks, etc. Another example, developed by the INRA, is a new concept called "MilUp" combining milk and lupin.

The complexity also stems from the mode of manufacturing. Large unit operations such as the fabrication of textures, aromas and functional matrices (pre- and probiotics, yeast dough, texturants) may be decoupled, after which these different matrices have to be re-assembled, resulting in a highly complex multi-functional matrix, as typified in the Fromlnnov concept (patent WO2016108024).

Added complexity comes from the end-to-end chain conditions, including storage and distribution. Dehydration and rehydration then texturization are critical in long chains. A key example here is the new INRA-developed milk powder (patent WO2016016397).

Directly related to matrix complexity is the challenge of obtaining appropriate technical or nutritionhealth functionalities. Technical functionalities (e.g. melting or spreading behavior, crispiness, etc.) are dependent on the biochemical profile of the matrix and its protein-mineral-lipid complexes. Nutritional functionalities are strongly related to the potential vectorizability of molecules-of-interest (like peptides, bioactive microorganisms or immune-modulators), the preservation of their mode of action during delivery in the digestive tract, and their uptake. Here again, the encompassing matrix plays a crucial role in terms of providing stability and release control.

Functionalized products - produced via a reverse engineering approach-should preferably have a "clean label", exclusively utilizing dairy ingredients. One major challenge is to design and deliver textures based on appropriate protein assemblies without any additional additives. Attempts to phase out today's antifungal chemical compounds hinge on developing an integrated fermentation process involving mixed cultures of micro-organisms with acidifying, aromatizing and antifungal properties, which is far from trivial (see the PROFIL project above).

Finally, functionalized food products should be produced via eco-friendly production routes and verified using multi-criteria evaluation schemes and expert databases. The data, if well-documented and categorized using state-of-the-art knowledge engineering approaches (see elsewhere in this special issue), can then be properly exploited utilizing decision support tools that integrate environmental, product, process and economics parameters. The SD2P software tool is an example.

This area of dairy food science and emerging technology innovation poses a number of scientific questions: (i) do we understand the complexity of food matrices and their functionalities enough to avoid negative side effects for specific target groups? (ii) can we define a 'book of knowledge' for designing intelligent processing methods? (iii) how can we create decision support tools based on multi-criteria analysis schemes to select appropriate technologies when there are so many variables?

\subsection{Towards an innovative dairy food science and technology agenda}

The French dairy chain has arrived at a strategic turning point in its rich history. The national market is mature, with a structural tendency towards less milk consumption, less place for fresh products, and stable cheese consumption, but with a new balance towards convenience products for on-the-go consumption and functional dairy foods (spinning, gratin, slides...) with increased fats and powders.

All prospective scenarios on the short- and long-term development of the French dairy sector show a pattern of convergence towards strong internationalization of innovative dairy products (Prospects 
for the cow milk sector by 2030 - France AgriMer, June 2015), so it is vital to integrate the diversity and availability of resources and the needs, preferences and acceptances of consumers.

Within these perspectives, five major themes co-emerge:

i. The first concerns the design of environmentally efficient and intensified processes in complex industrial systems at a global scale (Perrot et al, 2011). In fact, the concentration of industrial activities in the dairy sector tends towards the production of various products at a single location. So far, technological approaches have so far been linear and single-product output-oriented. Today, technological approaches are becoming increasingly integrated with multiple outputs, often of non-food developing into a complex multi-scale system that requires a high level of knowledge and modelling integration. In this sense, the dairy industry could serve as the reference model for heading towards eco-efficiency and eco-design of complex food systems (Xu et al, 2009). A key example is the novel eco-efficient process for milk powder production (Garreau et al, 2016) that cuts out the energy-intensive drying step by increasing the dry matter of the concentrate.

ii. The second theme concerns the concept of quality of dairy products via a reversed engineering approach that considers all dimensions of food quality characteristics as starting points for the selection, optimization or radical modification of processing steps. Vice versa, adopting these processing pathways may result in (potentially) new product functionalities of products. The best example is given by the cheese chain, representing $40 \%$ of national dairy volume. The optimization of traditional individual transformation processes only partially allows the development of new functionalities, as all transformation steps are interdependent (Jeantet et al, 2017). For example, the processes for the creation of texture and aroma need to be first decoupled, as shown for butter in the 1980s, and afterwards reintegrated. A first revolutionary step has been the new MMV process (Maubois -Mocquot Vassal) that now serves as basis for the development of the cheeses of tomorrow (Garric et al, 2016). The MMV process, by reversing the coagulation and draining steps, made it possible to better recover the serum proteins and make cheeses of constant weight. We also proposed decoupling the ripening step in order to obtain ready-to-eat cheese only two days after its manufacturing phase. This avoids managing temperature, humidity and maintenance of ripening cellars.

iii. The third major theme concerns the matrix of potentially interesting micro-organisms for the transformation of dairy resources into dairy products, especially for those with a long shelflife. The 'omics' methods help in determining the optimal microbial assemblies - the microbial ecosystems in a food context - and their evolution all along the life span of food products in order to end up with most preferred functionalities (Le Boucher et al, 2013). This includes in particular also the digestion steps and the understanding of interactions between gut flora and microbial assemblies in the dairy matrix (Jeanson et al, 2013). Also here, a reversed engineering approach is most appropriate in order to focus on required functions and functionalities.

iv. The fourth, a more cross-cutting theme-relevant for dairy products envisaged for largescale export-is related to transport and distribution costs but also to the reduction of food losses and environmental impact, which are objectively followed by detailed LCA studies, and the ambition to strive for appropriate quality at the end of the various chains. This requires gaining new insight into the 'drying-conservation-rehydration' triptych in order to understand and adapt the evolution of complex food matrices-with or without microbial assemblies-in different logistics pathways.

v. The fifth and final theme is also related to quality, but this time the enormous diversity of regional cheese products, often in smaller volumes (Figure 1), all of which contribute to the image of France as a major producer of high-quality cheese and a leading source of both traditional and innovative food products. The challenges are related to adequate marketing 
strategies, competitive short food supply chains and long distribution channels, and certified product quality schemes.

\section{Case 4: The cereal chain, with a particular focus on durum wheat}

\subsection{The French cereal sector}

Cereal farming covers $14 \%$ of the world's agricultural surface. In Europe, cereal production is dominated by 6 countries: France, Germany, Poland, the UK, Italy, and Spain. The main cereal crops are common (or soft) wheat (45\%), corn (21\%) and barley (20\%). Triticale, rye, durum wheat, oat and sorghum are also farmed, but at more modest scale. France is the largest producer of cereals in Europe, mainly common wheat, corn grain, barley, and durum wheat, but also 6 other cereals (Abecassis et al, 2009). Here we focus on durum wheat, which in contrast to common wheat is almost exclusively intended for human consumption after industrial processing.

\subsection{The durum wheat chain and its objectives}

The durum wheat chain is highly professionally organized by all public and private actors, including 5 economic interest groups (EIG) focusing on genetic varieties, 50 seed multiplication enterprises, 20,000 durum wheat farmers, 125 organizations collecting and storing durum wheat, 6 semolina millers, 8 pasta manufacturing factories, 4 couscous manufacturing factories, and 2 factories manufacturing precooked or crushed durum wheat grains. The entire sector is also served by experimental farms and large pilot-scale facilities for grain fractionation and secondary processing, such as the one shown in figure 2 .

Figure 2. Durum wheat mill pilot plant (left: grinding section; right: sifting section), a key facility at the plant product processing technology platform in Montpellier.

In response to user and consumer quality requirements, all French stakeholders in the durum wheat chain have collaborated to jointly define product quality ambitions for intermediate and final products. These ambitions are related to production volumes and efficiencies, and to product characteristics (glassy appearance, composition and properties of semolina, etc.) to obtain marketables like pastas of amber yellow colour that cook out as consumers expect. Joint action in the last few years (Sissons et al, 2012) has defined the following objectives:

- The identification of shared quality criteria for durum wheat products has served to define common goals for basic and applied research; examples are to understand the physicalchemical basis of quality of pasta, and to develop novel, generic varietal screening methods.

- The creation of an EIG focusing on the genetic improvement of durum wheat has allowed to pool genetic resources between public institutes and private breeders. The development of high-throughput screening methods has helped identify and design productive varieties that also meet both qualitative and disease-resistance objectives.

- The development of a novel tool called "wheat advice" links market requirements and product quality directly to the appropriate agronomic strategies.

- The development and implementation of new-often intensified-processing technologies such as the centrifugal-based rapid semolina hydration process for the production of pasta or couscous, high-temperature pasta-drying, or the co-fractionation and adapted extrusion processes for mixed vegetable protein products. These developments have contributed to a better value-streaming of French durum wheat and its high quality and nutrition potential. For instance, the use of the centrifugal wetting equipment in the industrial couscous-grain production lines enables better control of agglomeration yield with a more uniform 
distribution of the size of the wet agglomerates, which can increase agglomeration yield twofold while decreasing the recycled flow of over-fine agglomerates. Recent work based on the concept of powder engineering science has demonstrated hydration process-specific mechanisms. Another example concerns overheated steam, which has long been in use in pasta and couscous plants either for pre-cooking or drying end-products. One of the major problems has been the degradation of the integrated insolating panels in dryers due to vapor condensation. This issue is now overcome thanks to the use of highly-insulating materials and perfect sealing of the panels. Drying technologies have also been improved by optimizing air distribution and dew-point control, especially in the cooling stages. All these improvements have resulted in energy savings.

\subsection{Challenges in the French durum wheat chain}

The French durum wheat chain faces numerous challenges and in therefore continuously asking for deeper insights in cereal science and innovation. Key challenges are:

Climate change: After a period of substantial growth, durum wheat yields levelled off fifteen years ago due to global warming, drought and irregular rainfall, especially in the Mediterranean Basin. Hydric stress and specific pests (Juroszek \& Tiedemann, 2013) have affected the production yield and quality of durum wheat products. Beyond these technical consequences, climate change can have important socioeconomic impacts, threatening global production as well as the survival of numerous traditional SMEs and cooperatives. Note that durum wheat products are part of the Mediterranean diet, the first non-materialistic asset on the Unesco intangible cultural heritage list.

Evolution of new environmental regulations: The recently adopted nitrate directive has a severe impact on the durum wheat chain and may lead to significant reductions in yield as well as protein content, with consequences on end-product quality. Hence, innovation is needed to find creative solutions both in production and processing (see below). In addition, discussing a quality premium for durum wheat-based products is strongly recommended in the context of the new common agricultural policy reform. Certain regions in Europe may rapidly lose competitiveness due to higher production costs compared to other cereals (common wheat). Finally, renewed focus on value recovery from co-products of entire cereal plants, like the lignocellulosic part or hulls of the grains, for biomaterials and functional molecules and, in part, bio-energy fits with in the latest bio-economy concepts that focus on cascading the use of plant constituents (Abecassis et al., 2014).

Agronomic stakes: The durum wheat chain has to find levers to maintain high yield and quality while reducing its environmental impact and external inputs use (INRA, CEMAGREF, 2005). This imposes ecological intensification schemes with rotations taking into account preceding crops, as well as the definition of new disease resistance strategies via genetic selection and the development of new biocontrol methods. These agronomic questions should be tackled not just at field level (Herrera et al, 2009) but also at a more systemic level spanning territorial production, processing (Kaushik et al, 2009) and distribution up to final consumption, locally and globally (Brunori et al, 2016).

Qualitative and technological challenges: History has shown that the durum wheat chain knows how to meet the expectations of industries and consumers for quality products obtained via appropriate processing schemes (Ruiz et al, 2014; Cuq et al, 2014). However, the new challenges require a rethink of current practices, including reflexion on recurring defects (Perilli et al, 2010), increasing fluctuations in quality profiles of harvested grains, diversification of agricultural practices and varieties. Durum industries should also improve their processes to improve the health (Rios et al, 2009; Uygun et al, 2008) and nutritional quality (Barron et al, 2012; Rosa-Sibakov et al., 2015) of their products, and thus innovate with new processes and new food products. Figure 3 gives an example for an innovative French baguette based on durum wheat. Overall, the manufacturing industries need to improve their processing flexibility to address the clallenges of (increasing) 
heterogeneity of resources, substantial energy savings, local socio-economic conditions, marketing strategies for traditional products and processes, and more (Esnouf et al, 2015).

Figure 3: The new $100 \%$ durum wheat French baguette. A comparison of baguettes is shown, all based on the same durum wheat but produced utilizing different milling processes. The patented durum wheat flour (LA MIE'nutie) was developed by INRA, Arterris, Moulins Pyrénéens, and the Fédération Régionale de la Boulangerie Pâtisserie du Languedoc-Roussillon.

\subsection{Towards an innovative cereal food science and technology agenda}

In order to respond to the challenges set out above, a series of innovation actions and science programs have been initiated that are product-oriented, technological and organizational in nature.

The organizational innovation has been the setup and execution of the Durum Wheat Platform, created in 2011 (INRA, ARVALIS, 2013). This platform brings together all actors within the durum wheat chain, including private stakeholders, cooperative structures, academic research institutions and applied research centers. Their aim is to jointly prioritize the most important challenges and the execution of science and innovation projects. This hinges on all platform members sharing a common vision for their future, under the slogan "produce more, better ". Accordingly, the ambitions are to improve the economic competitiveness and environmental performance of the whole durum chainfrom wheat production up to semolina and pasta production-and short- and long-term research and development projects addressing one or more potential innovations. This approach has yielded a better mobilization of forces, the exploration of public-private research and innovation platforms, and the strengthening of synergies between academic research (INRA, SupAgro), applied research (Arvalis) and economic actors involved as breeders (IEG BD), producers, coops, collectors and manufacturers (CFSI-SIFPAF), all in one 'ecosystem'.

The product-oriented and technological innovations are currently envisaged in public-private research and development projects. These projects are geared to addressing:

- the optimization of current processing lines, e.g. for pasta and couscous production

- including full system control in processing lines utilizing in-line non-intrusive monitoring via intelligent sensors, such as optical sensors to control the size distribution and types of particles generated by the milling processes, or NIR sensors to check product water content.

- including new insights in granular matter, as needed to substantially innovate the processing of couscous in order to avoid re-processing to obtain appropriate couscous structures. A systemic powder engineering approach was proposed to meet powder production and usage requirements by integrating disciplines related to food science and technology with academic disciplines such as process engineering, physical chemistry, or physics. A solid understanding of the behavior of granular matter constituted by dense assemblies of solid heterogeneous grains under external stresses remains highly relevant here.

- New insights in biochemistry on structures and functional and nutritional properties of multiple proteins (such as glutenin polymers and gliadins), especially for mixed protein resources like cereal-legume matrices. Here, the volume and mass fractions of proteins, their profiles, nutritional functionalities and textural behavior are to be addressed in an integrative manner encompassing both the fractionation of agro-resources (as in co-grinding) and the structuration of matrices (as in extrusion).

- Overall, research is needed to better understand the structure-function relationships of durum-wheat products as a function of dynamic conditions all along the agri-food chain- 
relationships that include environmental, processing, storage and transport factors as well as consumption and health benefits (Fifth World Pasta Congress, 2015).

The future points to mixed organizational and technological innovations in new international cooperations, especially in the Mediterranean Basin and in higher education and training. The Durum Platform thus stands as an exemplary partnership approach as it draws new modes of research and open innovation.

\section{Discussion and conclusions}

France has traditionally built up strong food chains and adapted its basic research and innovation strategies to achieve high food quality output. The French agro-food sector is a world-leader in numerous chains, but globalization is putting pressure on its chain approach. Here, we described each case in a somewhat different way, as explained in the introduction, to clearly emerge these pressures. The durum wheat chain, for example, faces strong competition from abroad. The meat chain suffers an image deficit due to associations with disease and environmental impacts. The dairy sector faces saturation of markets, and the wine sector is severely impacted by climate changes.

Each of these chains is therefore seeking innovations that will help them improve economically, environmentally, nutritionally and socially. These innovations are part organizational (e.g. new public-private partnerships), part product-technological (see below), and/or part communicational, including new marketing strategies, labels for territorial products, etc. Since food products, especially in Europe, are often strongly rooted in tradition and cultural heritage, the French food sector continues to support both larger-scale, globally-oriented food chains but also, and crucially, territorial and local-to-local and local-to-global value chains. These innovations are not only chainoriented but increasingly either inter-chain or even cross-sector-oriented. A clear example is the value-streaming of waste and co-products in a cascading bio-economy process in which all constituents are optimally and ecologically value-streamed, as shown in the cases for meat (e.g. ligaments as source of elastin), cereals (e.g. lignocellulosic part of the grain hulls) and wine (non-food applications of polyphenols). This takes us up from (linear) chains and toward the (complex) system.

Food science and technology is still very much tied to a food chain orientation. Sustainable, addedvalue approaches for specific products, competing with other products in similar chains, remain a primary ambition. The focal processing steps thus strive to optimize and up-value product quality while reducing environmental impact, which is where life cycle analysis actions emerge potentially interesting pathways, as for example indicated in the dairy and meat cases. Numerous improvements are expected in this area in the coming decades, especially if all co-products are to be transformed into final end-products (food and non-food) in an effort to optimally utilize our renewable resources.

A major focus point remains getting a better understanding of the meaning of food quality, for either characteristics of the end-product or the intermediates depending on the in-chain interventions. Consumer science has assisted in understanding quality in terms of consumer preferences, acceptance and needs. Nutrition and health-oriented research continuously unearths new quality characteristics in terms of nutritional and health impact. Process engineering methods provide insights into process-structure-function relationships. Novel packaging and storage systems yield knowledge on preserving the stability, shelf life and keeping quality of food, as illustrated in the wine case. Biobased sciences pave the way to redefining quality in terms of multiple products and their spectrum of required functionalities throughout a chain and inter-connected chains (thus more at a system level), in a way that is directly or indirectly related to the agro-resources mobilized. The search for appropriate, non-intrusive, highly-sensitive, in-line sensor devices is imperative. Consequently, the concept of food quality is continuously re-challenged. 
In the emerging technology area, we are seeing numerous innovative pathways that are generically important and increasingly based on a reverse engineering approach starting with the quality required by consumers. The four cases studied here highlight the following topics: process intensification integrating a variety of transformation steps, smart process control utilizing in-line sensors, packaging and other ways of preserving product quality in chains, and food-omics, especially for food microbiology in the wider context (contamination, fermentation, digestion, etc.). At a more systemic level, industrial complex systems, either within a single industry or in an industrial ecology context, are becoming more apparent. Striving for eco-efficiency in transformation processes and useful utilization of all heterogeneous agro-resources-including by-product and waste streamsrequires a permanent pipeline of new insights in food engineering.

In the food science area, the spotlight is strongly on protein science, spanning dairy, cereal, legume and meat sector proteins. The sustainable and intelligent exploitation of all protein resources for our diets, for animal feed and pet food, and for non-food applications, is a key topic in numerous science and innovation programs. Efforts are directed towards finding new sources, new functionalities and technicalities, new insights into the complex structures of proteins under diverse conditions, alternative nutritional profiles in food, but also the necessary alternatives to synthetic products. Here again, the inter-connections between chains, for example between either cereals and legumes or vegetable proteins partially replacing meat proteins, provide opportunities for new food products, as in the meat case, but also new and adapted processes like co-grinding, as in the cereal case.

The need to deepen the science base for food assemblies - in separate food chains-has recently led to new collaborations with soft matter scientists, mathematicians and computer scientists to unravel complex systems, and with nutrition and medical scientists to understand decomposition processes, food component intake and health consequences, and so on. In-diet interactions of food products from different chains, mixed-protein foods, ready-to-eat meals, etc., all increase interactions between chains, adding layers of complexity and posing new questions for the area of food science and emerging technologies in the future, both at chain level and at a more systemic level.

\section{$\underline{\text { Perspectives }}$}

The historical basis of the food industry as a multi-food supply chain sector is still well anchored today. It has continuously led to new scientific and innovation projects, and is largely expected to continue doing so, given the numerous opportunities and bottlenecks that remain, and that we can summarize as generic perspectives shaping food science and technology for the future:

- Sustainable processing: the continuous drive to reduce the footprint of single chains by more efficiently utilizing resources per $\mathrm{kg}$ of final product. This is a single-supply-chain concern leading to agendas for each chain; however, it is also a sector and (inter)national concern warranting recommendations, exchange of best practices and targeted support mechanisms to address general topics such as the reduction of fertilizer input and its consequences here, with special focus on alternative strategies, e.g. based on physical principles like mechanical interventions - to reduce and recycle energy and water, etc.

- Added value creation: competition between big businesses, between big and small businesses, and between small businesses will repetitively lead to new product and technology developments. The past decades, for example, have driven a substantial increase in convenience products and the development of minimal processing equipment. Hence, the supply chains themselves will create their own dynamics, as the opportunities are substantial and the challenges are very different between large- and small-scale production. However, it is also of public interest, in the case local or national assets, to find opportunities to create better added value, e.g. food quality of local, often niche products in relation to place branding and typically authentic local assets (cultural, environmental, social, etc), which is 
where value chain research stems in (Porter, 1985). Here, the diversity aspect of food quality science, including objective markers for quality, warrants special attention, along with new technologies and packaging concepts that better reveal the biodiversity of food products while guaranteeing better food health safety.

- Novel technology implementation: the existence, pros and cons of novel technology and packaging concepts are often not well known by SMEs, making it urgent to support a longterm accessible and updated technology database with key features and application potential for numerous product chains. Next, it would be wise to couple and rethink product chain-related infrastructures and equipments to exchange best practices between technologies developed for specific supply chains. A specific focus on technologies that are competitive at small-scale is also highly recommended, as pointed out elsewhere in this Special Issue ('Engineering food processes at small scale-challenges and perspectives')

- An in-depth international cross-sector review of food supply chains would be helpful in order to extract, via a knowledge engineering approach (artificial intelligence, argumentation models, etc.), new generic scientific topics like oxidation phenomena, structure-function relationships, etc., but also new emerging scientific questions, such as LCA studies and multicriteria evaluations of processes and systems.

- Finally, food science and technology should be much stronger linked to agronomy, health, and socio-economics sciences in a chain context and inter-chain concept for mixed food products, and particularly organic food, which extended LCA studies have shown is needed. It is often the case that scientific insights are not exchanged in a science chain perspective, which is becoming increasingly critical for understanding resilience and long-term sustainability in the face of external drivers and challenges such as impacts of climate change, soil erosion and urbanization on food quality and diversity, as a step towards developing quality markers in the full food supply chain.

\section{Acknowledgements}

The authors like to greatly acknowledge their colleagues of the UE Pech Rouge, UR QuaPa, UMR STLO and UMR IATE for all their research and innovation activities, creativity, thoughts and results in the described food chain cases.

\section{$\underline{\text { References }}$}

- Abecassis J, Bergez JE, 2009. Les Filières Céréalières, Organisation et nouveaux défis, Éditions Quae, Paris, pp. 165.

- $\quad$ Abecassis J., de Vries H., Rouau X, 2014. New perspective for bio-refining cereals. Biofuels, Bioproducts and Biorefining 8: 462-474

- $\quad$ AFSSA, 2007. Apports en protéines: consommation, qualité, besoins et recommandations. Synthèse du rapport de I'AFSSA, Maisons-Alfort., AFSSA, 64 pages.

- $\quad$ Agence Française pour le Développement et la Promotion de l'Agriculture Biologique, Agence Bio, 2015. Available at: http://www.agencebio.org/les-editions-des-chiffres-cles

- $\quad$ ANIA (2016) http://www.ania.net/presentation-de-lania/les-federations-sectorielles

- Barron C, Abécassis J, Chaurand M, Lullien-Pellerin V, Mabille F, Rouau X, Sadoudi A, Samson MF, 2012. Accès à des molécules d'intérêt par fractionnement par voie sèche. Innovations Agronomiques 19: 51-62.

- Bax ML., Buffière C, Hafnaoui N, Gaudichon C, Savary-Auzeloux I, Dardevet D, Santé-Lhoutellier V, Rémond $D, 2013$. Effects of meat cooking, and of ingested amount, on protein digestion speed and entry of residual proteins into the colon: a study in minipigs. PlosOne 8(4): e61252.

- Bombrun L, Gatellier P., Carlier M, Kondjoyan A, 2014. The effects of low salt concentrations on the mechanism of adhesion between two pieces of pork semimembranosus muscle following tumbling and cooking, Meat Science 96(1), 5-13. 
- $\quad$ Bombrun L, Gatellier P, Portanguen S, Kondjoyan A, 2015. Analysis of the juice and water losses in salted and unsalted pork samples heated in water bath. Consequences for the prediction of weight loss by transfer models. Meat Science 99: 113-122.

- $\quad$ Bourlieu C, Michalski M-C, 2015. Structure -function relationship of the milk fat globule. Current Opinion in Clinical Nutrition and Metabolic Care 18(2): 118-127.

- $\quad$ Brunori G, Galli F, Barjolle D, van Broekhuizen R, Colombo L, Giampietro M, Kirwan J, Lang T, Mathijs E, Maye D, de Roest K, Rougoor C, Schwarz J, Schmitt E, Smith J, Stojanovic Z, Tisenkopfs T, Touzard J.-M, 2016. Are local food chains more sustainable than global food chains? Considerations for assessment. Sustainability 8 (5): 449.

- $\quad$ Cuq B, Abecassis J, Morel MH, 2014. La physique et la chimie au service de la qualité des pâtes alimentaires. In Sciences Culinaires, 52-73, Collection Echelles, Belin.

- De Vries H, 2017. Some thoughts about the bio-economy as intelligently navigated complex adaptive systems. In: Knowledge-driven developments in the Bioeconomy - Technological and economic perspectives. Eds. Dabbert S., Lewandowski I., Pyka A., Weiss J. Springer-Verlag series.

- Dequin S, Escudier J.L, Bely M, Noble J, Albertin W, Mesneuf-Pomarede I, Marullo P, Salmon J.M, Sablayrolles J.M, 2016. How to adapt winemaking practices to modified grape composition under climate change conditions? CLIMWINE Congress, Journal International des Sciences de la Vigne et du Vin OenoOne, 9 p., in press.

- DucheneC, Gandemer G, 2016) Effet de la cuisson sur la composition et les valeurs nutritionnelles des viandes, Viandes et Produits Carnés, A paraitre (2016).

- $\quad$ Economie laitière en chiffres, CNIEL, Edition 2016

- $\quad$ Escudier JL, Bes M, Salmon JM, Caillé S, Samson A, 2014. Stress hydrique prolongé des vignes : comment adapter les pratiques œnologiques en conséquence? Innovations Agronomiques 38: 67-86.

- $\quad$ Escudier JL, Bes M, Samson A, Mikolajczak M, Moutounet M, Salmon JM, 2012. CEnologie de précision: exemples à partir d'actions de R \& D menées à l'Inra Pech Rouge. Revue des CEnologues 142: 7-8.

- $\quad$ Esnouf C, Russel M, Bricas N, 2011. Pour une alimentation durable; reflexion stratégique duALine. Editions Quae, ISBN 978-2-7592-1670-3; 286 pages

- $\quad$ Esnouf C, Fioramonti J, Laurioux B, 2015. Alimentation à découvert. CNRS Editions, Paris, pp 324.

- $\quad$ FAO, 2009. The State of Food and Agriculture. Livestock in the Balance. Rome: FAO.

- $\quad$ Fifth World Pasta Congress, 2015. Healthy Pasta Meals Scientific Consensus Statement. 5th World Pasta Congress, Milan, Italy, 26/10/2015. http://oldwayspt.org/resources/food-project-orphan-pagesfound/pasta/2015-healthy-pasta-meals-scientific-consensus

- FoodandDrinkEurope, 2016. http://www.fooddrinkeurope.eu/about-us/members/\#tab2

- Fournier D, 2014. Analyse bibliométrique des publications 2008-2012 sur la vigne et le vin V\&V et positionnement de I'Inra. Paris: INRA. 53 p, Available at: http://prodinra.inra.fr/record/256989

- $\quad$ Garreau D, Schuck P, Dolivet A, Sai G, Mejean S, Jeantet R, Vezzani M, 2016. Milk powder. WO2016016397.

- Garric G, Leonil J, Jeantet R, Lortal S, Schuck P, Gaucheron F, 2016. Procédé pour la fabrication d'une denrée alimentaire fromagère, avantageusement du type fromage, spécialité fromagère ou substitut de fromage. WO2016108024.

- Gassi J-Y, Blot M, Beaucher E, Robert B, Leconte N, Camier B, Rousseau F, Bourlieu C, Jardin J, Briard-Bion V, Lambert S, Gésan Guiziou G, Lopez C, Gaucheron F, 2016. Preparation and characterisation of a milk polar lipids enriched ingredient from fresh industrial liquid butter serum: Combination of physico-chemical modifications and technological treatments. International Dairy Journal 52: 26-34.

- Grunert KG, 2005. Food quality and safety: consumer perception and demand. European Review of Agricultural Economics 32(3): 369-391.

- $\mathrm{Gu} \mathrm{Y,} \mathrm{Wu} \mathrm{J,} \mathrm{2016.} \mathrm{The} \mathrm{potential} \mathrm{of} \mathrm{antioxidative} \mathrm{and} \mathrm{anti-inflammatory} \mathrm{peptides} \mathrm{in} \mathrm{reducing} \mathrm{the} \mathrm{risk} \mathrm{of}$ cardiovascular diseases. Current Opinion in Food Science 8: 25-32.

- Gwanpua SG, Verboven P, Leducq D, Brown T, Verlinden BE, Bekele E, Aregawi W, Evans J, Foster A, Duret S, Hoang HM, van der Sluis S, Wissink E, Hendriksen LJAM, Taoukis P, Gogou E, Stahl V, El Jabri M, Le Page JF, Claussen I, Indergård E, Nicolai BM, Alvarez G, Geeraerd AH, 2015. The FRISBEE tool, a software for optimising the trade-off between food quality, energy use, and global warming impact of cold chains. Journal of Food Engineering 148: 2-12.

- Harkouss R, Astruc T, Lebert A, Gatellier P, Loison O, Safa H, POortanguen S, Parafita E, Mirade P-S, 2015. Quantitative study of the relationships among proteolysis, lipid oxidation, structure and texture throughout the dry-cured ham process. Food Chemistry 166(1): 522-530. 
- Herrera J, Estopanan G, Ariño A, 2009. Comparison of deoxynivalenol, ochratoxin A and aflatoxin B1 levels in conventional and organic durum semolina and the effect of milling. Journal of Food and Nutrition Research 48: 92-99.

- Hocquette J-F, van Wezemael L, Chriki S, Legrandl, Verbeke W, Farmer L, Scollan ND, Polkinhorne R, Rodbotten R, AllenP, Pethick DW, 2014. Modelling of beef sensory quality for a better prediction of palatability. Meat Science 97(3): 316-322.

- HighTechEurope (2016) http://www.foodtech-portal.eu/index.php?title=Main Page

- Inra, Cemagref, 2005. Pesticides, agriculture et environnement: Réduire l'utilisation des pesticides et en limiter les impacts environnementaux, Expertise scientifique collective, Inra, Paris, Cemagref-Anthony, 66p. http://institut.inra.fr/Missions/Eclairer-les-decisions/Expertises/Toutes-les-actualites/Pesticidesagriculture-et-environnement

- Inra, Arvalis-Institut du végétal, 2013. Compétitivité, qualité, durabilité : les acteurs de la filière blé dur mobilisés sur un programme ambitieux de recherche et d'innovation.

http://presse.inra.fr/Ressources/Communiques-de-presse/CP-Ble-dur

- Jeanson S, Floury F, Issulahi A, Madec MN, Thierry A, Lortal S, 2013. Microgradients of pH do not cccur around Lactococcus colonies in a model cheese. Applied and Environmental Microbiology 79(20): 6516-18.

- Juroszek P, Tiedemann P, 2013. Climate change and potential future risks through wheat diseases: a review. European Journal of Plant Pathology 136(1): 21-33.

- $\quad$ Kaushik G, Satya S, Naik SN, 2009. Food processing a tool to pesticide residue dissipation. A review. Food Research Internationa, 42: 26-40.

- Kondjoyan A, Chevolleau S, Greve E, Gatellier P, Santé-Lhoutellier V, Bruel S, Touzet C, Portanguen S, Debrauwer L, 2010a. Formation of heterocyclic amines in slices of Longissimus thoracis beef muscle subjected to jets of superheated steam. Food Chemistry 119(1): 19-26.

- Kondjoyan A, Chevolleau S, Greve E, Gatellier P, Santé-Lhoutellier V, Bruel S, Touzet C, Portanguen S, Debrauwer L., 2010b. Modelling of the formation of heterocyclic amines in slices of Longissimus thoracis and semimembranosus beef muscles subjected to jets of hot air. Food Chemistry 123(3): 659-668.

- $\quad$ Le Boucher C, Courant F, Jeanson S, Chereau S, Maillard M-B, Royer AL, Thierry A, Dervilly-Pinel G, Le Bizec $B$, Lortal S, 2013. First mass spectrometry metabolic fingerprinting of bacterial metabolism in a model cheese. Food Chemistry 141: 1032-1040.

- Martin A, 2001. Apports nutritionnels conseillés pour la population française. 3red edition. Paris. Tec \& Doc. Lavoisier: 605 pages.

- Matharu AS, de Melo EM, Houghton JA, 2016. Opportunity for high value-added chemicals from food supply chain wastes. Bioresource Technology 215: 123-130.

- NOAW, 2017). EU project 'valorization of agricultural waste' http://noaw2020.eu/about-noaw/

- $\quad$ Ojeda H, Rousseau J, Zumstein E, Heywang M, Lacapère J-N, Sivry A, 2016. Innovation variétale et étude agronomique. Partie 3/3: Sélection des cépages et conduite du vignoble pour une production de jus de raisin aux caractéristiques prédéfinies. Revue des CEnologues 158: 22-24.

- Pelletier C, 2015. Réflexions sur la nature humaine, le leadership et le défi de nourrir une population en croissance. Demande croissante en viande: quelques chiffres-clés pour le futur. Viandes et Produits Carnés 31: 1-3.

- $\quad$ Perilli P, Mitchell L.G, Grant C, Pisante M, 2010. Cadmium concentration in durum wheat grain (Triticum turgidum) as influenced by nitrogen rate, seedling date and soil type. Journal of the Science of Food and Agriculture 90: 813-822.

- $\quad$ Perrot N, Trelea IC. , Baudrit C, Trystram G, Bourgine P, 2011. Modelling and analysis of complex food systems: State of the art and new trends. Food Science \& Technology 22: 304-14

- $\quad$ Prospects for the cow milk sector by 2030 - France AgriMer, June 2015

- $\quad$ Plance C, Ratel J, Mercier F, Blinet P, Debrauwer L, Eengel E, 2015. Assessment of comprehensive twodimensional gas chromatography-time-of-flight mass spectrometry based methods for investigating 206 dioxin-like micropollutants in animal-derived food matrices. Journal of Chromatography A 1392(1): 74-81.

- $\quad$ Promeyrat A, Daudin JD, Gatellier P, 2013. Kinetics of protein physicochemical changes induced by heating in meat using mimetic models: (1) Relative effects of heat and oxidants. Food Chemistry 138(1): 581-589.

- $\quad$ Rios G, Pinson-Gadais L, Abecassis J, Zakhia-Rozis N, Lullien-Pellerin V, 2009b. Assessment of dehulling efficiency to reduce deoxynivalenol and Fusarium level in durum wheat grains. Journal of Cereal Science, 49: 387-392.

- $\quad$ Rosa-Sibakov N, Poutanen K, Micard V, 2015. How does wheat grain, bran and aleurone structure impact their nutritional and technological properties? Trends in Food Science \& Technology 41: 118-134. 
- $\quad$ Ruiz T, Rondet E, Cuq B, 2014. La graine de couscous: de l'artisanat à la croissance fractale. In Sciences Culinaires, p. 28-51, Collection Echelles, Belin.

- Saguer E, FortN, Alvarez J, Sednam J, Ismail AA,2008. Structure-functionality relationships of porcine plasma proteins probed by FTIR spectroscopy and texture analysis. Food Hydrocolloids 22(3): 459-467.

- Salmon JM, 2010. Retrait du règlement européen sur la vinification biologique : risques et opportunités pour le développement de la viticulture biologique en France. Revue des CEnologues 137: 8-9.

- Salmon J.M, 2012. Technological tools for minimizing the use of chemical inputs during winemaking. Progrès Agricole et Viticole 18: 423-427.

- $\quad$ Scholtz K, Eriksson M, Strid I, 2015. Carbon footprint of supermarket food waste. Resources, Conservation and Recycling 94: 56-65.

- Sébillotte M, Aigrain P, Hannin H, Sébillotte C, 2003. Prospective: Vignes et vins. Scénarios et défis pour la recherche et les acteurs. Paris: INRA. 406 p. (coll. Bilan et Prospectives). Available at: http://www6.paris.inra.fr/depe/Publications/Archives-DADP

- $\quad$ Sissons M, Abecassis J, Marchylo B, Carcea M, 2012. Durum wheat chemistry and technology ( $2^{\text {nd }}$ edition). AACC International Press, St Paul, pp 300.

- $\quad$ Supply Chains, 2016. https://en.wikipedia.org/wiki/Supply_chain

- Toussaint M, Vidal JC, Salmon JM, 2014. Comparative evolution of oxygen, carbon dioxide, nitrogen, and sulfites during storage of a rosé wine bottled in PET and glass. Journal of Agricultural and Food Chemistry 62: 2946-2955.

- $\quad$ TradelT, 2016. http://www.tradeitnetwork.eu/TRADEIT--Support-for-the-Traditional-FoodSector\#\&panel1-1

- Trafoon, 2016. http://www.trafoon.eu/

- Trioli G, Hofmann U, Comuzzo P, Cottereau P, van de Meer M, Levite D, Jonis M, Werner M, Rauhut D, Salmon JM, Fragoulis G, Barbier JM, Zironi R, Tat L, Scobioala S, 2009. Code of good organic viticulture and wine making. 235 p. Six ${ }^{\text {th }}$ Framework programme. Edited by ECOVIN, Federal association of organic wine producers. Available at http://www.orwine.org

- $\quad$ USEN. Étude nationale nutrition santé, ENNS, 2006. Situation nutritionnelle en France en 2006 selon les indicateurs d'objectif et les repères du Programme national nutrition santé (PNNS). Bobigny. Institut de veille sanitaire, Université de Paris 13, Conservatoire national des arts et métiers. 2007, 74 p.

- $\quad$ Uygun U, Senoz B, Koksel H, 2008. Dissipation of organophosphorus pesticides in wheat during pasta processing. Food Chemistry 109; 355-360.

- Vialis S, Shea P, Vidal JC, Vuchot P, 2011. La mesure de l'oxygène total au conditionnement en BIB. Élément clé de la durée de vie du vin. Revue des CEnologue, 140: 44-46.

- $\quad$ Xu T, Flapper J, Jan Kramer K, 2009. Characterization of energy use and performance of global cheese processing. Energy 34: 1993-2000. 
Figure 1. A map of the regions in France with all their typical cheese products

Figure 2. Durum wheat mill pilot plant (left: grinding section; right: sifting section), a key facility at the plant product processing technology platform in Montpellier.

Figure 3: The new $100 \%$ durum wheat French baguette. A comparison of baguettes is shown, all based on the same durum wheat but produced utilizing different milling processes. The patented durum wheat flour (LA MIE'nutie) was developed by INRA, Arterris, Moulins Pyrénéens, and the Fédération Régionale de la Boulangerie Pâtisserie du Languedoc-Roussillon. 


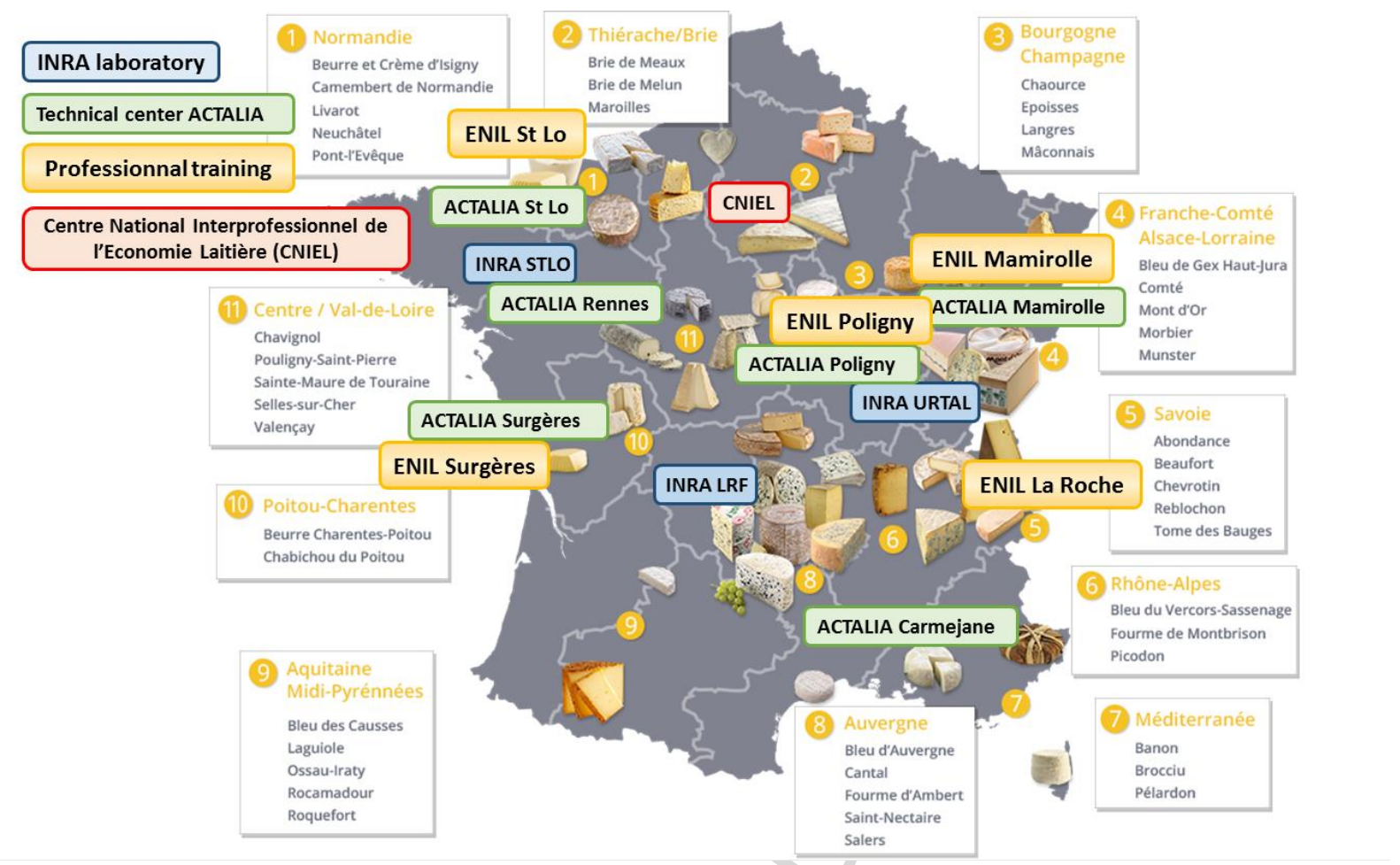

Fig. 1 

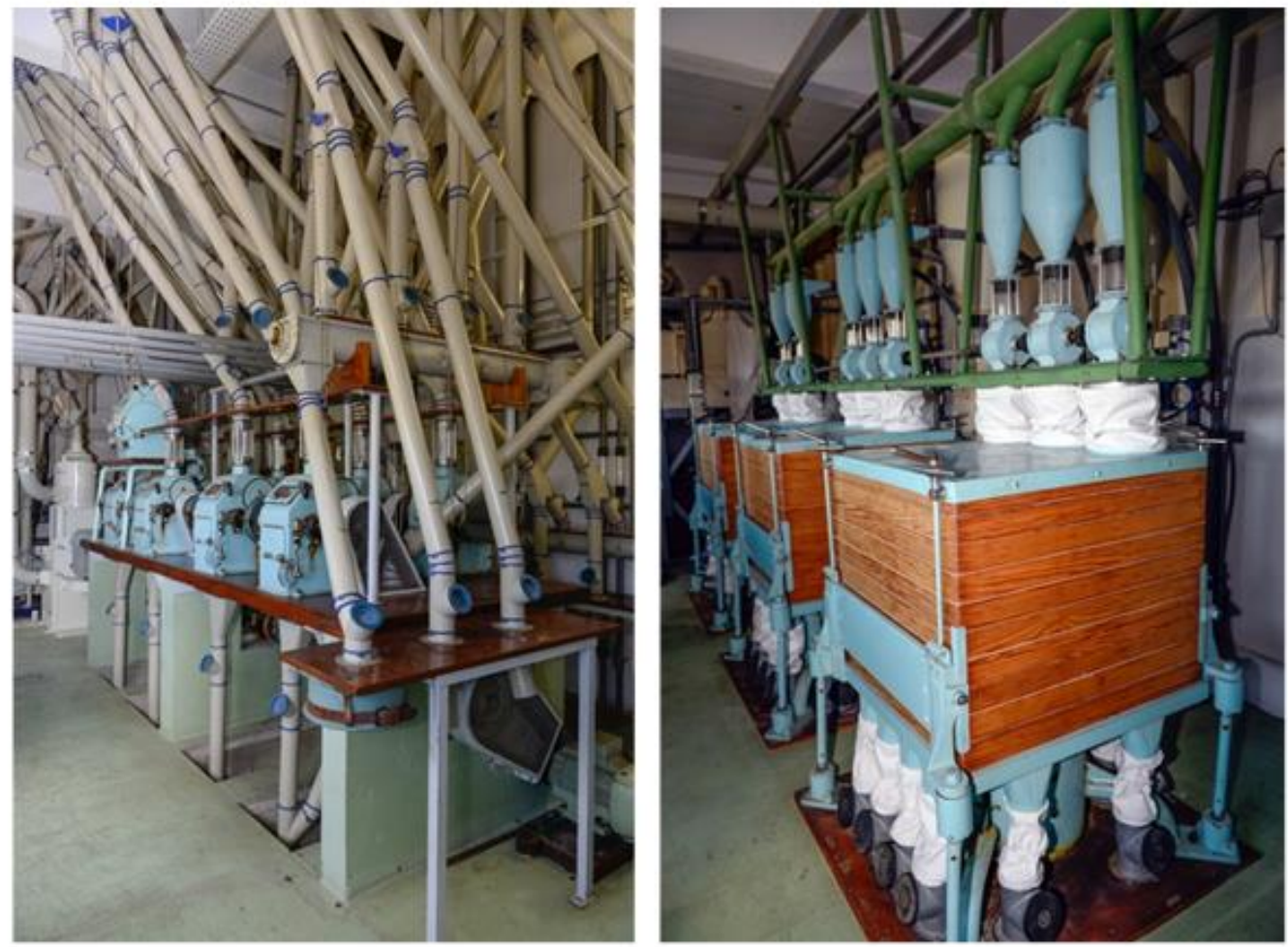

Fig. 2

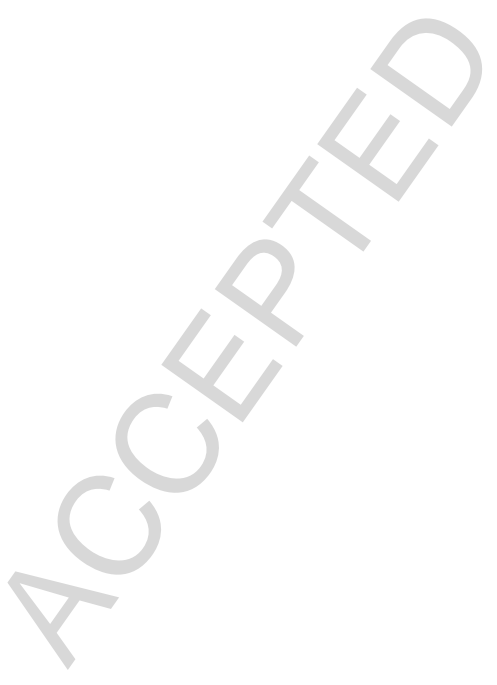




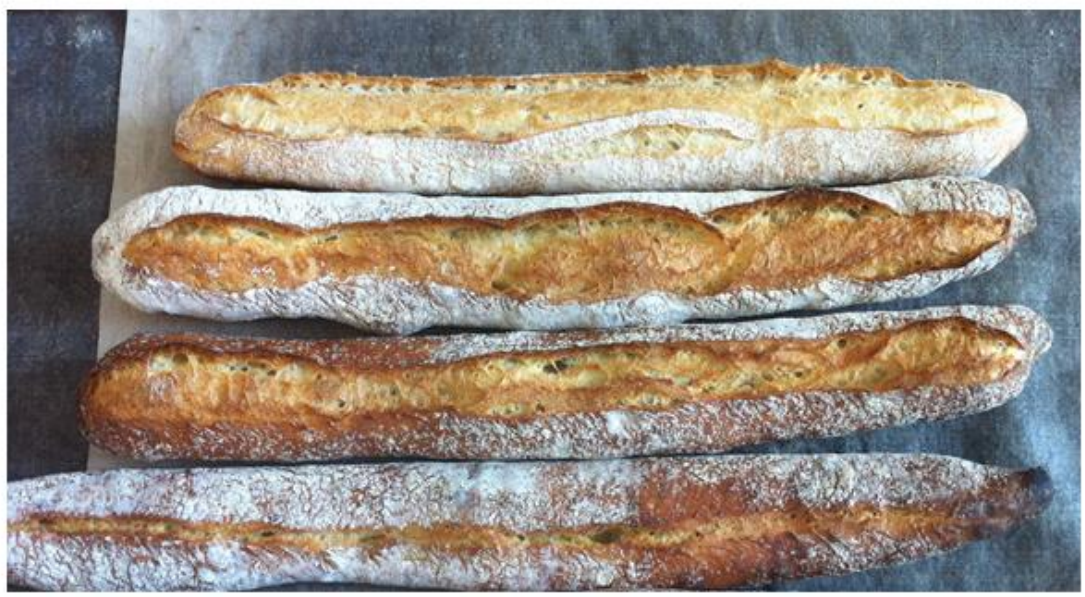

Common wheat

Durum wheat flour (patented)

Durum remilled semolina

Traditional flour from semolina mill

Fig. 3

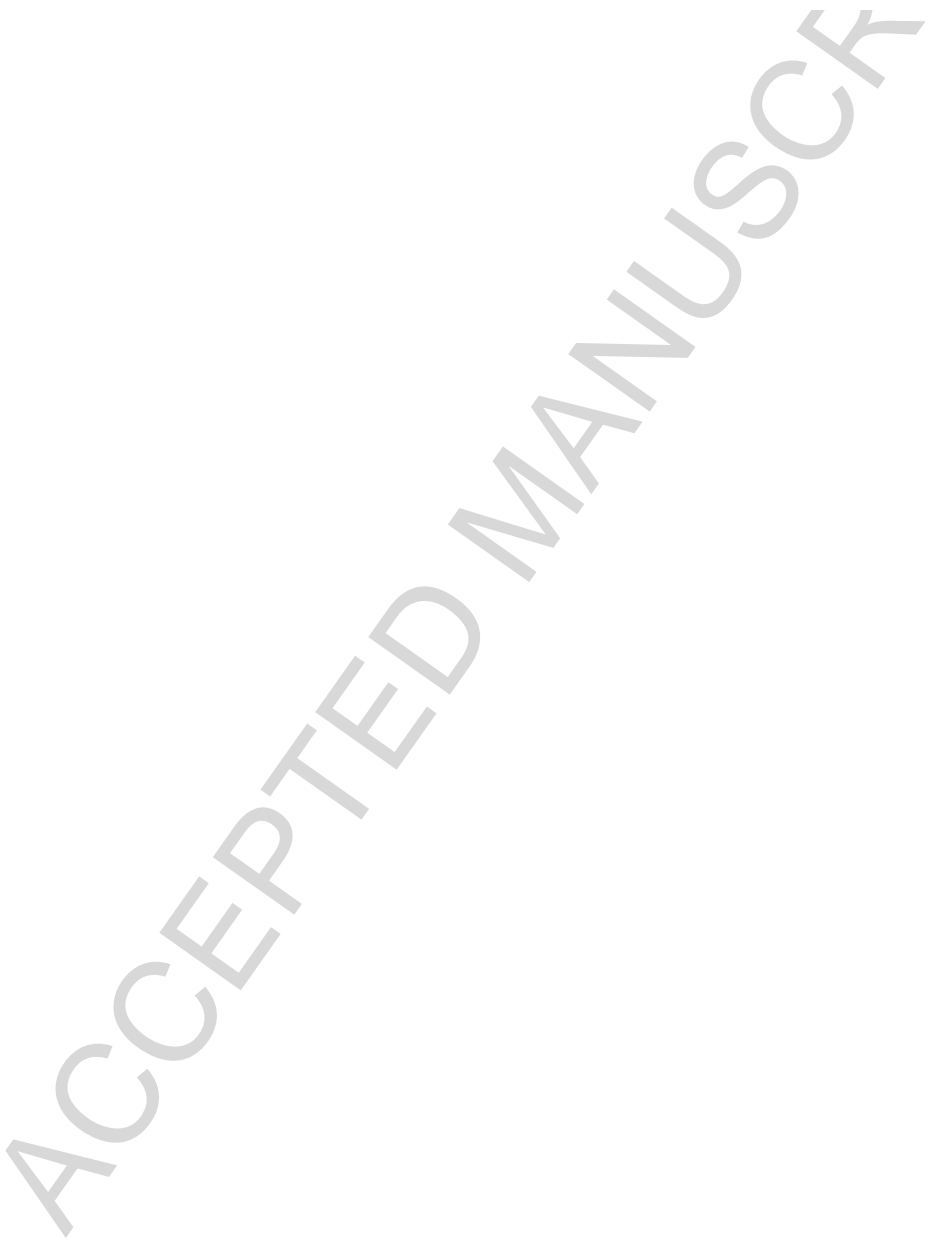

Comment citer ce document : 
Highlights : Food Chains; the cradle for scientific ideas and the target for technological innovations

- $\quad$ Food chain research is still the cradle of many new research and innovation topics

- A cross-cutting view on food chain research emerges a number of generic food science and technology topics, such as plant protein science, ecodesign approaches, and food-system thinking

- Environmental pressure on food systems is driving closer cooperation between all scientists all along the food chain

- Food science is becoming an increasingly inter-disciplinary and inter-sector cooperation effort 